\title{
Performance enhancement of diammonium hydrogen phosphate as halogen and formaldehyde free sustainable fire retardant
}

\author{
DOI: 10.35530/IT.070.04.1606
}

\section{REZUMAT - ABSTRACT}

\author{
Îmbunătățirea performanței hidrogenofosfatului de diamoniu ca ignifugant durabil fără halogen \\ și formaldehidă
}

\begin{abstract}
Ignifuganții pe bază de fosfor sunt utilizați în general pentru a conferi un caracter ignifug țesăturii de bumbac. Cu toate acestea, majoritatea ignifuganților eficienți pe bază de fosfor pentru textile conțin halogen toxic și/sau formaldehidă. Hidrogenofosfatul de diamoniu nu conține halogen sau formaldehidă, dar performanța sa este mult mai mică decât a substanțelor ignifuge disponibile în comerț. Prin urmare, în acest studiu, hidrogenofosfatul de diamoniu a fost polimerizat cu agenți de reticulare fără conţinut de formaldehidă, cum ar fi acidul acrilic și acidul maleic. Concentrațiile de monomeri și inițiatori, condițiile de polimerizare și temperatura au fost optimizate. Țesătura tratată pe baza noii rețete a prezentat performanțe bune de ignifugare, precum și proprietăți suplimentare ale controlului contracției, îngrijire ușoară și proprietăți antimicrobiene. Testarea analitică SEM, FTIR și a conținutului de fosfor a confirmat, de asemenea, aplicarea cu succes a finisajului.
\end{abstract}

Cuvinte-cheie: ignifugant, finisare cu îngrijire ușoară, controlul contracției, antimicrobian, sare de fosfat

\section{Performance enhancement of diammonium hydrogen phosphate as halogen and formaldehyde free sustainable fire retardant}

Phosphorous based fire retardants are commonly used for imparting fire retardancy to the cotton fabric. However, most of theeffective phosphorous based fire retardants for textile contain toxic halogen and/or formaldehyde. Diammonium hydrogen phosphate does not contain halogen or formaldehyde but its performance is far less than the commercially available fire retardants. Therefore, in this research Diammonium hydrogen phosphate was polymerized with zero formaldehyde based cross-linkers like acrylic acid and maleic acid. Concentrations of monomers and initiator, polymerization conditions and temperature were optimized. Newly developed recipe treated fabric exhibited good fire retardancy performance as well as additional properties of shrinkage control, easy care and anti-microbial. Analytical testing of SEM, FTIR and phosphorous content also confirmed the successful application of the finish.

Keywords: fire retardant, easy carefinishing, shrinkage control, anti-microbial, phosphate salt

\section{INTRODUCTION}

Fire play vital role in our lives. However, it is very dangerous when out of control. Over 0.3 million people die andmany more get injured while billions of loss in property is reported every year due to fire breakout. According to fire hazard statistics of United State of America 2015, the fire department has responded to an estimated 1,345,500 fire incidents; over 1570 civilians died during these fire incidents and 14.3 billion dollar direct property loss was reported [1-2]. Carpets, upholstery and most importantly textile apparel are the last barrier for fire before it can cause harm to humans. Therefore, fire retardant chemicals consumption are increasing and it was worth more than 5.6 billion pounds in 2017. There is no doubt that cotton is the most widely used natural fiber but it lacks fire retardancy, in fact it will spread more fire once ignited [3-5].

It is unfortunate that the most widely used fire retardants for textile like Pyrovatex CP New (modified
$\mathrm{N}$-methyloldimethylphosphonopropionamide) and THPC (Tetrakishydroxymethylphosphonium chloride) are not environment friendly. Pyrovatex contain carcinogenic formaldehyde while THPC required nonconventional and non-environment friendly ammonia chamber [6-9].

Zero discharge of hazardous chemicals (ZDHC) program, vision 2020 and its signatory brands have included the conventional effective halogenated fire retardants in their 11 banned priority chemicals. In addition, certifications for organic textile products also prohibit the use of halogen and formaldehyde based fire repellents. Therefore, researchers are working on finding the effective alternatives. Ammonium phosphate salts are one such alternative [10] but its performance is far less than the commercial Pyrovatex and THPC. Carboxylic acids are good alternative for formaldehyde based cross-linkers [11-14]. Researchers have reported the use of butane tetra carboxylic acid (BTCA) as fire retardant enhancer with Pyrovatex but BTCA is very expensive and 
Pyrovatexitself is toxic. Certain cost effective carboxylic acids like maleic acid (di carboxylic acid) with C6 fluorocarbon has been reported as oil and water repellent [15] while acrylic acid (mono carboxylic acid) as surface modifier for textile fabric.

Diammonium hydrogen phosphate (DAHP) has been reported as environment friendly, non-toxic and cost effective fire retardant for textile. However, its performance is much less than the commercially available products. Researchers have reported the use of melamine formaldehyde [16] as enhancer with DAHP but melamine formaldehyde contains carcinogenic formaldehyde. In this research DAHP is polymerized withformaldehyde freecross-linkers; maleic acid and acrylic acid under normal atmosphere and nitrogen atmosphere at various conditions. The performance of the newly polymerized recipes was assessed on the cotton fabric.

\section{EXPERIMENTAL WORK}

\section{Materials and methods}

In this research $100 \%$ cottonbleached fabric with 280 GSM was used. Following lab grade chemicals; Diammonium hydrogen phosphate (DAHP), sodium hypophosphite (SHSP), acrylic acid, potassium per sulfate (PPS) and maleic acid were purchased from Sigma Aldrich.

\section{Methods}

In this research non-toxic and formaldehyde free cross-linkers like acrylic acid and maleic acid have been used along with halogen free fire retardant monomer; diammonium hydrogen phosphate (DAHP). Concentrations of DAHP and cross-linkers as well as temperature of polymerization were optimized. The polymerization time was optimized for one hour. Potassium per sulfate was used as initiator and sodium hypophosphite as catalyst. The polymerized recipe was applied through padding by using $80 \%$ pick up. Drying was carried out at hundred degrees for three minutes while curing was performed at one hundred and eighty degrees for two minutes. All the samples were conditioned at $65 \%$ relative humidity and $20^{\circ} \mathrm{C}$ prior to any testing. Limiting oxygen index was assessed by the standard method of ASTM D 2863. BS 5438: 1989, Test 2B vertical burning test was performed to measure the damaged char length and width. Crease recovery and shrinkage were assessed by using BS EN 22313: 1992 and AATCC test method 135: 2004 respectively. AATCC 147 test method was performed to determine the antimicrobial performance. The air permeability was measured by using method D737: 1996. Olsen method [17] was used to measure the concentration of phosphorous. FTIR was also performed for samples with 32 background scan and from wave number range of 650 to $4000 \mathrm{~cm}^{-1}$. Gold coating treatment was carried out before performing SEM analysis.

\section{RESULTS AND DISCUSSIONS}

Untreated control cotton fabric was burnt immediately and completely. One of the most commonly used fire retardant for textile, Pyrovatex, has been used as bench mark in this study. Manufacturer suggested recipe of $20 \%$ Pyrovatexalong with $1.5 \%$ of formaldehyde based trimethylol melamine catalyst $\mathrm{CHN}$ and $2.5 \%$ of phosphoric acid was applied on to the treated fabric. The treated samples have exhibited the char length of $98 \mathrm{~mm}$ and char width of $32 \mathrm{~mm}$ (table 1). By raising the quantity of Pyrovatex from $20 \%$ to $40 \%$ there was further improvement in the fire retardancy, consequently, char length and width of $64 \mathrm{~mm}$ and $28 \mathrm{~mm}$ respectively were obtained (table 1). Performance of the diammonium hydrogen phosphate (DAHP) was also assessed at the level of $5 \%$, $10 \%, 20 \%$ and $40 \%$. Char length and width were reduced by increasing the quantity of DAHP. The reduction in char length and width is higher at low levels of DAHP and slowed down after $20 \%$ due to saturation effect.

\begin{tabular}{|c|c|c|c|}
\hline \multicolumn{4}{|c|}{ FIRE RETARDANCY OF PYROVATEX } \\
AND DIAMMONIUM HYDROGEN PHOSPHATE \\
TREATED COTTON \\
\hline $\begin{array}{c}\text { Fire } \\
\text { retardant } \\
\text { chemical }\end{array}$ & $\begin{array}{c}\text { Catalyst/ } \\
\text { Cross-linker }\end{array}$ & $\begin{array}{c}\text { Char } \\
\text { length } \\
\text { (mm) }\end{array}$ & $\begin{array}{c}\text { Char } \\
\text { width } \\
\text { (mm) }\end{array}$ \\
\hline $\begin{array}{c}\text { Control fabric } \\
\text { Tmmete } \\
20 \%\end{array}$ & $\begin{array}{c}\text { Complete } \\
\text { burn }\end{array}$ & $\begin{array}{c}\text { Complete } \\
\text { burn }\end{array}$ \\
\hline $\begin{array}{c}\text { Pyrovatex, } \\
\text { acid 2.5\%, }\end{array}$ & 98 & 32 \\
\hline $\begin{array}{c}\text { Pyrovatex, } \\
40 \%\end{array}$ & $\begin{array}{c}\text { Phosphoric acid 6\%, } \\
\text { Catalyst (CHN) 2.2\% }\end{array}$ & 64 & 28 \\
\hline DAHP, 5\% & - & 184 & 46 \\
\hline DAHP, 10\% & - & 142 & 41 \\
\hline DAHP, 20\% & - & 101 & 32 \\
\hline DAHP, 40\% & - & 95 & 28 \\
\hline
\end{tabular}

\section{Preparation of fire retardant and its application} to the cotton fabric

The cotton fabric treated with maleic acid was burnt completely and did not show any kind of fire retardancy. Table 2 represent the results of polymerization at normal atmosphere. Increasing the polymerization temperature from $25^{\circ} \mathrm{C}$ to $120^{\circ} \mathrm{C}$ exhibited reduction in the char length. Nevertheless, polymerization temperature greater than $120^{\circ} \mathrm{C}$ imparted no improvement.

Alone acrylic acid treated cotton fabric was also burnt completely. Table 3 exhibited the results of polymerization between DAHP and acrylic acid where atmosphere is not controlled. In the case of acrylic acid polymerization with DAHP the char length was decreased by raising the temperature from $25^{\circ} \mathrm{C}$ to $90^{\circ} \mathrm{C}$ and after that there was no improvement. 
EFFECT OF TEMPERATURE ON POLYMERIZATION OF MALEIC ACID AT NORMAL ATMOSPHERE

\begin{tabular}{|c|c|c|c|c|}
\hline $\begin{array}{c}\text { Fire retardant } \\
\text { chemical DAHP (\%) }\end{array}$ & $\begin{array}{c}\text { Cross linker } \\
\text { Maleic acid (\%) }\end{array}$ & $\begin{array}{c}\text { Polymerization } \\
\left.\text { temperature } \mathbf{(}^{\circ} \mathbf{C}\right)\end{array}$ & $\begin{array}{c}\text { Char length } \\
(\mathbf{m m})\end{array}$ & $\begin{array}{c}\text { Char width } \\
(\mathbf{m m})\end{array}$ \\
\hline- & 5 & - & Complete burn & Complete burn \\
\hline- & 10 & - & Complete burn & Complete burn \\
\hline- & 15 & 25 & 136 & Complete burn \\
\hline 10 & 10 & 80 & 129 & 41 \\
\hline 10 & 10 & 100 & 126 & 36 \\
\hline 10 & 10 & 120 & 119 & 33 \\
\hline 10 & 10 & 140 & 119 & 33 \\
\hline 10 & 10 & 160 & 134 & 37 \\
\hline 10 & 10 & & & \\
\hline
\end{tabular}

Table 3

EFFECT OF TEMPERATURE ON POLYMERIZATION OF ACRYLIC ACID AT NORMAL ATMOSPHERE

\begin{tabular}{|c|c|c|c|c|}
\hline $\begin{array}{c}\text { Fire retardant } \\
\text { chemical DAHP (\%) }\end{array}$ & $\begin{array}{c}\text { Cross linker } \\
\text { Acrylic acid }(\%)\end{array}$ & $\begin{array}{c}\text { Polymerization } \\
\left.\text { temperature } \mathbf{~}^{\circ} \mathbf{C}\right)\end{array}$ & $\begin{array}{c}\text { Char length } \\
(\mathbf{m m})\end{array}$ & $\begin{array}{c}\text { Char width } \\
(\mathbf{m m})\end{array}$ \\
\hline- & 5 & - & Complete burn & Complete burn \\
\hline- & 10 & - & Complete burn & Complete burn \\
\hline- & 15 & - & Complete burn & Complete burn \\
\hline 10 & 10 & 25 & 129 & 33 \\
\hline 10 & 10 & 50 & 116 & 31 \\
\hline 10 & 10 & 75 & 102 & 31 \\
\hline 10 & 10 & 90 & 70 & 30 \\
\hline 10 & 10 & 100 & 72 & 30 \\
\hline
\end{tabular}

Typically, lot of side reactions can take place under atmospheric conditions. In addition, nitrogen in combination with phosphorous can improve the fire retardancy of the fabric. Therefore, polymerization was also performed in nitrogen atmosphere. Improved fire retardancy was achieved when polymerization was carried out under nitrogen atmosphere with DAHP and maleic acid. The minimum char length and width was achieved at the polymerization temperature of $120^{\circ} \mathrm{C}$ (table 4 ).

Similarly, acrylic acid was also polymerized with DAHP in nitrogen atmosphere. The minimum burnt char length and width was observed at $90^{\circ} \mathrm{C}$ as shown in table 5 . Similarly the improvement in the char length and width can easily be noticed when the polymerization was carried out under nitrogen atmosphere as compared to normal atmosphere.

Diammonium hydrogen phosphate was polymerized with maleic acid and acrylic acid without catalyst and initiator, with catalyst and without initiator, with catalyst and initiator under nitrogen atmosphere at $120^{\circ} \mathrm{C}$ and $90^{\circ} \mathrm{C}$ respectively as shown in table 6 . Potassium per sulfate was also used in polymerization because it is a well-known initiator. In addition, sodium hypo phosphite has been reported as catalyst for carboxylic acids [11], consequently, it was used in the

Table 4

EFFECT OF TEMPERATURE ON POLYMERIZATION OF MALEIC ACID UNDER NITROGEN ATMOSPHERE

\begin{tabular}{|c|c|c|c|c|}
\hline $\begin{array}{c}\text { Fire retardant } \\
\text { chemical DAHP (\%) }\end{array}$ & $\begin{array}{c}\text { Cross linker } \\
\text { Maleic acid (\%) }\end{array}$ & $\begin{array}{c}\text { Polymerization } \\
\left.\text { temperature } \mathbf{~}^{\circ} \mathbf{C}\right)\end{array}$ & $\begin{array}{c}\text { Char length } \\
(\mathbf{m m})\end{array}$ & $\begin{array}{c}\text { Char width } \\
(\mathbf{m m})\end{array}$ \\
\hline 10 & 10 & 25 & 113 & 36 \\
\hline 10 & 10 & 80 & 109 & 34 \\
\hline 10 & 10 & 100 & 95 & 33 \\
\hline 10 & 10 & 120 & 85 & 21 \\
\hline 10 & 10 & 140 & 90 & 25 \\
\hline 10 & 10 & 160 & 91 & 24 \\
\hline
\end{tabular}


EFFECT OF TEMPERATURE ON POLYMERIZATION OF ACRYLIC ACID UNDER NITROGEN ATMOSPHERE

\begin{tabular}{|c|c|c|c|c|}
\hline $\begin{array}{c}\text { Fire retardant } \\
\text { chemical DAHP (\%) }\end{array}$ & $\begin{array}{c}\text { Cross linker } \\
\text { Acrylic acid (\%) }\end{array}$ & $\begin{array}{c}\text { Polymerization } \\
\left.\text { temperature ( }{ }^{\circ} \mathbf{C}\right)\end{array}$ & $\begin{array}{c}\text { Char length } \\
(\mathbf{m m})\end{array}$ & $\begin{array}{c}\text { Char width } \\
\text { (mm) }\end{array}$ \\
\hline 10 & 10 & 25 & 88 & 39 \\
\hline 10 & 10 & 50 & 97 & 30 \\
\hline 10 & 10 & 75 & 68 & 28 \\
\hline 10 & 10 & 90 & 26 & 27 \\
\hline 10 & 10 & 100 & 39 & 28 \\
\hline
\end{tabular}

\begin{tabular}{|c|c|c|c|c|c|c|c|}
\hline \multicolumn{6}{|c|}{ EFFECT OF CATALYST AND INITIATOR ON POLYMERIZATION UNDER NITROGEN ATMOSPHERE } \\
\hline $\begin{array}{c}\text { Fire retardant } \\
\text { chemical }\end{array}$ & $\begin{array}{c}\text { Cross } \\
\text { linker }\end{array}$ & $\begin{array}{c}\text { Cross } \\
\text { linker }\end{array}$ & Catalyst & Initiator & $\begin{array}{c}\text { Polymerization } \\
\text { temperature } \\
\text { ( } \mathbf{C})\end{array}$ & $\begin{array}{c}\text { Char } \\
\text { length } \\
\text { (mm) }\end{array}$ & $\begin{array}{c}\text { Char } \\
\text { width } \\
\text { (mm) }\end{array}$ \\
\hline $\begin{array}{c}\text { DAHP } \\
(\%)\end{array}$ & $\begin{array}{c}\text { Maleic acid } \\
(\%)\end{array}$ & Acrylic acid & $\begin{array}{c}\text { Sodium } \\
\text { hypophosphite (\%) }\end{array}$ & $\begin{array}{c}\text { Potassium per } \\
\text { sulfate (\%) }\end{array}$ & & & \\
\hline 10 & 10 & - & - & - & 120 & 85 & 21 \\
\hline 10 & 10 & - & 8 & - & 120 & 81 & 19 \\
\hline 10 & 10 & - & 8 & 0.01 & 120 & 66 & 19 \\
\hline 10 & 10 & - & 8 & 0.02 & 120 & 39 & 16 \\
\hline 10 & 10 & - & 8 & 0.03 & 120 & 43 & 22 \\
\hline 10 & - & 10 & & - & 90 & 26 & 27 \\
\hline 10 & - & 10 & 8 & - & 90 & 25 & 27 \\
\hline 10 & - & 10 & 8 & 0.1 & 90 & 19 & 26 \\
\hline 10 & - & 10 & 8 & 0.2 & 90 & 15 & 25 \\
\hline 10 & - & 10 & 8 & 0.3 & 90 & 16 & 25 \\
\hline
\end{tabular}

polymerization. The most effective results were obtained with catalyst and initiator. The optimum amount of potassium per sulfate was $0.02 \%$ as exhibited in table 6. Therefore, sodium hypophosphite and potassium per sulfate were used as catalyst and initiator respectively in the remaining research.
The diammonium hydrogen phosphate was polymerized with maleic acid and acrylic acid under nitrogen atmosphere with catalyst and initiator at optimum temperature with various levels of DAHP, maleic acid and acrylic acidas shown in table 7 . The optimum results were achieved when $10 \%$ diammonium hydrogen

Table 7

\begin{tabular}{|c|c|c|c|c|c|c|c|}
\hline \multicolumn{8}{|c|}{$\begin{array}{l}\text { EFFECT OF CONCENTRATION OF FIRE RETARDANT MONOMER AND CROSS-LINKER AT OPTIMUM } \\
\text { TEMPERATURE WITH CATALYST AND INITIATOR UNDER NITROGEN ATMOSPHERE }\end{array}$} \\
\hline $\begin{array}{l}\text { Fire retardant } \\
\text { chemical }\end{array}$ & $\begin{array}{l}\text { Cross } \\
\text { linker }\end{array}$ & $\begin{array}{l}\text { Cross } \\
\text { linker }\end{array}$ & Catalyst & Initiator & $\begin{array}{l}\text { Polymerization } \\
\text { temperature } \\
\left({ }^{\circ} \mathrm{C}\right)\end{array}$ & $\begin{array}{l}\text { Char } \\
\text { length } \\
(\mathrm{mm})\end{array}$ & $\begin{array}{l}\text { Char } \\
\text { width } \\
\text { (mm) }\end{array}$ \\
\hline $\begin{array}{l}\text { DAHP } \\
(\%)\end{array}$ & $\begin{array}{l}\text { Maleic acid } \\
\quad(\%)\end{array}$ & Acrylic acid & $\begin{array}{c}\text { Sodium } \\
\text { hypophosphite (\%) }\end{array}$ & $\begin{array}{l}\text { Potassium per } \\
\text { sulfate }(\%)\end{array}$ & - & - & - \\
\hline 10 & 5 & - & 8 & 0.01 & 120 & 53 & 24 \\
\hline 10 & 10 & - & 8 & 0.02 & 120 & 39 & 16 \\
\hline 10 & 15 & - & 8 & 0.03 & 120 & 40 & 17 \\
\hline 5 & 10 & - & 8 & 0.02 & 120 & 83 & 39 \\
\hline 10 & 10 & - & 8 & 0.02 & 120 & 39 & 16 \\
\hline 15 & 10 & - & 8 & 0.02 & 120 & 38 & 16 \\
\hline 10 & - & 5 & 8 & 0.1 & 90 & 21 & 25 \\
\hline 10 & - & 10 & 8 & 0.2 & 90 & 15 & 25 \\
\hline 10 & - & 15 & 8 & 0.3 & 90 & 33 & 30 \\
\hline 5 & - & 10 & 8 & 0.2 & 90 & 49 & 36 \\
\hline 10 & - & 10 & 8 & 0.2 & 90 & 15 & 25 \\
\hline 15 & - & 10 & 8 & 0.2 & 90 & 17 & 26 \\
\hline
\end{tabular}




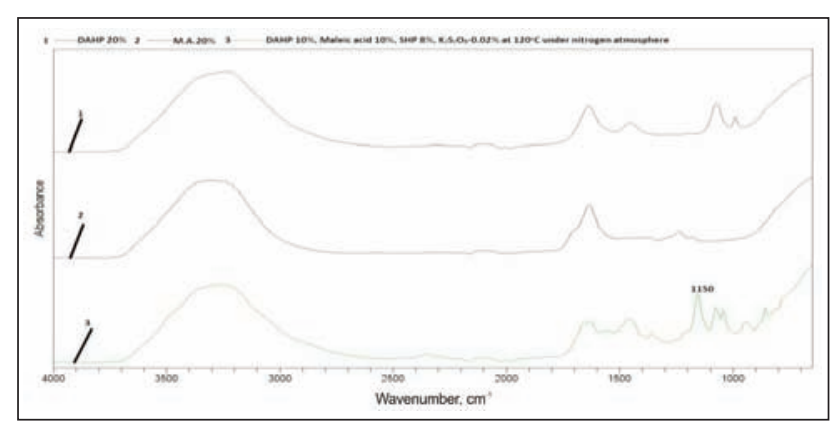

Fig. 1. FTIR analysis with maleic acid recipe

phosphate was polymerized with $10 \%$ maleic acid, $8 \%$ sodium hypophosphite and $0.2 \%$ potassium per sulfate. Similar conditions were repeated with $10 \%$ acrylic acid as well.

FTIR analysis were performed on the range of recipes; DAHP ( $20 \%$ solution in water), maleic acid ( $20 \%$ solution in water) and best polymerized recipe with maleic acid as shown in figure 1. FTIR were also performed on acrylic acid ( $20 \%$ solution in water) and best polymerized recipe with acrylic acid, figure 2 . The optimized recipes in case of maleic acid and acrylic acid along with DAHP, sodium hypophosphite, potassium per sulphate at $120^{\circ}$ under nitrogen atmosphere exhibited the prominent ester peaks at 1150 $\mathrm{cm}^{-1}$ and $1161 \mathrm{~cm}^{-1}$ respectively. Consequently, formation of effective ester bonding can be confirmed from the FTIR analysis. P-O-C stretch has been exhibited at the 920-1088 $\mathrm{cm}^{-1}$ for DAHP and best recipe either with maleic acid or acrylic acid, however, no such peak can be observed for alone maleic acid or acrylic acid.

\section{Physical and mechanical properties of cotton fabric}

Measurement of fire retardancy through objective testing like limiting oxygen index (LOI) \% is also important. Therefore, LOI \% of the selected samples was also performed. More the percentage of LOI better will be the fire retardancy. LOI of the control fabric was $18.1 \%$ indicating that it will easily catch the fire. Similarly, the maleic acid (20\%) and acrylic acid $(20 \%)$ treated fabric imparted the LOI\% of $18.2 \%$, demonstrating that there is hardly any improvement in the fire retardancy of the treated fabric when both carboxylic acids are used. The benchmark sample of $40 \%$ Pyrovatex treated fabric exhibited good LOI\% of $34.1 \%$. 20\% DAHP treated fabric exhibited LOI\% of 24.1. In case of cotton fabric treated with $10 \%$ maleic acid along with $10 \%$ diammonium hydrogen phosphate, $8 \%$ sodium hypophosphite, $0.2 \%$ potassium per sulfate the best LOI reported was $29.1 \%$. However, the highest LOI\% of $34.8 \%$ was achieved when cotton fabric was treated with $10 \%$ acrylic acid, $10 \%$ DAHP, $8 \%$ sodium hypophosphite and $0.2 \%$ potassium per sulfate. It can easily be said from tables $7 \& 8$ that both char length-width and LOI\% demonstrated similar trends.

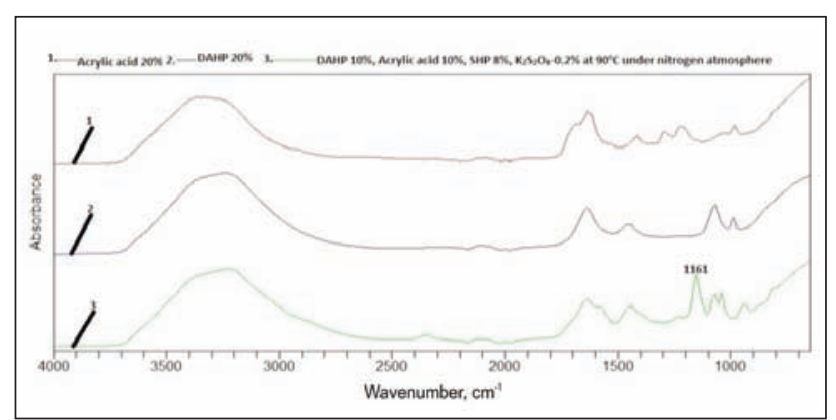

Fig. 2. FTIR analysis with acrylic acid recipe

Spread of fire through smoldering cigarette is very common all around the world. Therefore, smoldering cigarette test is performed on the cotton fabric samples. It was noticed as expected that control cotton fabric burnt easily. $40 \%$ Pyrovatextreated fabric was burnt in significant high time of 31 minutes. The highest burnt time of 32 minutes was achieved for the cotton fabric treated with DAHP $10 \%$,acrylic acid $10 \%$, catalyst $8 \%$ and initiator $0.02 \%$ (table 8 ).

Cotton fabric lacks the easy care properties and demonstrated the low crease recovery angle (table 8). It is mainly due to more amorphous region around $30 \%$ in the cotton as well as weak hydrogen bonding. Maleic acid and acrylic acid are both cross-linkers and consequently improved the bonding of the cellulose chains, therefore crease recovery is improved as compared to control cotton fabric. DAHP is not an effective cross-linker, therefore, improvement was minimal. However, crease recovery angle was significantly increased when DAHP10\% with maleic acid $10 \%$, catalyst $8 \%$ and initiator $0.2 \%$ were applied onto the fabric after the polymerization at $120^{\circ} \mathrm{C}$ under nitrogen atmosphere (table 8). It can also be concluded that due to new recipe effective bonding with the treated fabric, there was improvement in the fire retardancy and crease recovery angle.

One of the advantages of cotton fabric is its good air permeability. Therefore, control fabric air permeability is set as $100 \%$. Maleic acid, acrylic acid and DAHP exhibited slight decrease in the air permeability as these chemical coating on the cotton fabric will prevent the air permeability. Pyrovatex at the higher level of $40 \%$ exhibited the least air permeability retention of $69 \%$ due to more sever coating onto the cotton fabric at high dosage. The best recipe of maleic acid along with DAHP and others exhibited the reasonable air permeability retention of $86 \%$.

As mentioned above that cotton has amorphous region as well as weak hydrogen bonding, consequently, cotton fabric demonstrated shrinkage after washing due to lack of strong forces. However, maleic acid and acrylic acid treated fabric exhibited good shrinkage control due to the cross-linking of the cellulose chains. It was also not surprising that the best recipe of maleic acid along with DAHP, catalyst and initiator exhibited the best shrinkage control results due to their effective cross-linking.

Fire retardant finish performance can be determined through its phosphorous content as well. Therefore, 


\begin{tabular}{|c|c|c|c|c|c|c|}
\hline \multicolumn{7}{|c|}{ LOI\% OF VARIOUSFIRE RETARDANTS } \\
\hline Sample type & $\begin{array}{l}\text { Limiting } \\
\text { oxygen } \\
\text { index }(\%)\end{array}$ & $\begin{array}{l}\text { Crease } \\
\text { recovery } \\
\text { angle } \\
\text { (degree) }\end{array}$ & $\begin{array}{c}\text { Air } \\
\text { permeability } \\
\text { (\% retention) }\end{array}$ & $\begin{array}{c}\text { Shrinkage } \\
\text { of fabric } \\
\text { in warp } \\
\text { direction (\%) }\end{array}$ & $\begin{array}{l}\text { Shrinkage of } \\
\text { fabric in weft } \\
\text { direction (\%) }\end{array}$ & $\begin{array}{l}\text { Smoldering } \\
\text { cigarette test } \\
\text { results } \\
\text { (minutes) }\end{array}$ \\
\hline Control fabric & 18.1 & 137 & 100 & 7.6 & 6.2 & 11 \\
\hline Maleic acid & 18.2 & 208 & 91 & 2.2 & 1.1 & 12 \\
\hline Acrylic acid & 18.2 & 205 & 91 & 2.2 & 1.1 & 11 \\
\hline DAHP & 24.1 & 141 & 88 & 3.4 & 2.1 & 14 \\
\hline Pyrovatex $20 \%$ & 27.5 & 168 & 85 & 3.7 & 3.2 & 17 \\
\hline Pyrovatex $40 \%$ & 34.1 & 179 & 69 & 2.8 & 2.4 & 31 \\
\hline $\begin{array}{c}\text { DAHP } 10 \%+\text { Maleic acid } \\
10 \% \text { at } 120^{\circ} \mathrm{C} \text { under } \\
\text { nitrogen atmosphere }\end{array}$ & 24.8 & 195 & 87 & 2.1 & 1.6 & 15 \\
\hline $\begin{array}{c}\text { DAHP } 10 \%+\text { Acrylic acid } \\
10 \% \text { at } 90^{\circ} \mathrm{C} \text { under nitrogen } \\
\text { atmosphere }\end{array}$ & 25.1 & 189 & 88 & 2.1 & 1.6 & 16 \\
\hline $\begin{array}{c}\text { DAHP } 10 \%+\text { Maleic acid } \\
10 \%+\text { SHP } 8 \%+\mathrm{K}_{2} \mathrm{~S}_{2} \mathrm{O}_{8} \\
0.2 \% \text { at } 120^{\circ} \mathrm{C} \text { under } \\
\text { nitrogen atmosphere }\end{array}$ & 29.1 & 211 & 86 & 1.7 & 1.2 & 30 \\
\hline $\begin{array}{c}\text { DAHP } 10 \%+\text { Acrylic acid } \\
10 \%+\mathrm{SHP} 8 \%+\mathrm{K}_{2} \mathrm{~S}_{2} \mathrm{O}_{8} \\
0.2 \% \text { at } 90^{\circ} \mathrm{C} \text { under } \\
\text { nitrogen atmosphere }\end{array}$ & 34.8 & 208 & 86 & 1.8 & 1.2 & 32 \\
\hline
\end{tabular}

phosphorous content of the various fire retardant finishes were assessed. It was not surprising that distilled water, maleic acid and acrylic acid recipes exhibited no phosphorous content. Highest phosphorus content was achieved for $40 \%$ Pyrovatex treated fabric. Normally, $17,000 \mathrm{ppm}$ is considered enough for imparting fire retardancy. The best recipe of maleic acid, DAHP, catalyst and initiator exhibited good phosphorous content of $31,350 \mathrm{ppm}$ demonstrating the effectiveness of the finish (table 9).

The development of formaldehyde free fire retardant was the basic purpose of this research, therefore, formaldehyde content of the various finished fabric was assessed. Pyrovatex treated fabric exhibited the formaldehyde content confirming the presence of toxic formaldehyde in the treated fabric. However, no formaldehyde was detected in any of the fabric treated with maleic acid, acrylic acid and DAHP combination, thus confirming that the newly developed recipes are completely formaldehyde free (table 10).

\section{Surface morphology of finished cotton fabric}

The surface of the control cotton fabric was smooth and clean as evident from the image of scanning electron microscope (SEM), (figure 3,a). However, there was confirmation of the coating on the surface of the cotton fabric when it was treated with recipe containing DAHP10\%, maleic acid $10 \%$, catalyst $8 \%$

Table 9

\begin{tabular}{|c|c|}
\hline \multicolumn{2}{|c|}{ PHOSPHOROUS CONCENTRATION IN VARIOUS FIRE RETARDANTS } \\
\hline Item Name & Concentration of phosphorous (ppm) \\
\hline Distilled water & 0 \\
\hline Maleic acid 10\% & 0 \\
\hline Acrylic acid 10\% & 0 \\
\hline DAHP 10\% & $27,367.2$ \\
\hline Pyrovatex 20\% & $17,689.7$ \\
\hline Pyrovatex 40\% & $43,344.8$ \\
\hline $\begin{array}{c}\text { Maleic acid } 10 \%+\text { DAHP } 10 \%+\text { SHP } 8 \%+\mathrm{K}_{2} \mathrm{~S}_{2} \mathrm{O}_{8} 0.2 \% \text { polymerized } \\
\text { at } 120^{\circ} \mathrm{C} \text { under nitrogen atmosphere }\end{array}$ & $31,350.72$ \\
\hline $\begin{array}{c}\text { Acrylic acid } 10 \%+\text { DAHP } 10 \%+\text { SHP } 8 \%+\mathrm{K}_{2} \mathrm{~S}_{2} \mathrm{O}_{8} 0.2 \% \text { polymerized } \\
\text { at } 90^{\circ} \mathrm{C} \text { under nitrogen atmosphere }\end{array}$ & $31,378.18$ \\
\hline
\end{tabular}




\begin{tabular}{|c|c|}
\hline \multicolumn{2}{|c|}{ FORMALDEHYDE CONTENT IN FABRIC } \\
\hline Item Name & Formaldehyde content in fabric (ppm) \\
\hline DAHP $10 \%$ & 0 \\
\hline Pyrovatex $20 \%$ & 32 \\
\hline Pyrovatex $40 \%$ & 41 \\
\hline $\begin{array}{c}\text { Maleic acid } 10 \%+\text { DAHP 10\% }+ \text { SHP } 8 \%+\mathrm{K}_{2} \mathrm{~S}_{2} \mathrm{O}_{8} 0.2 \% \text { polymerized } \\
\text { at } 120^{\circ} \mathrm{C} \text { under nitrogen atmosphere }\end{array}$ & 0 \\
\hline $\begin{array}{c}\text { Acrylic acid } 10 \%+\text { DAHP } 10 \%+\text { SHP } 8 \%+\mathrm{K}_{2} \mathrm{~S}_{2} \mathrm{O}_{8} 0.2 \% \text { polymerized } \\
\text { at } 90^{\circ} \mathrm{C} \text { under nitrogen atmosphere }\end{array}$ & 0 \\
\hline
\end{tabular}

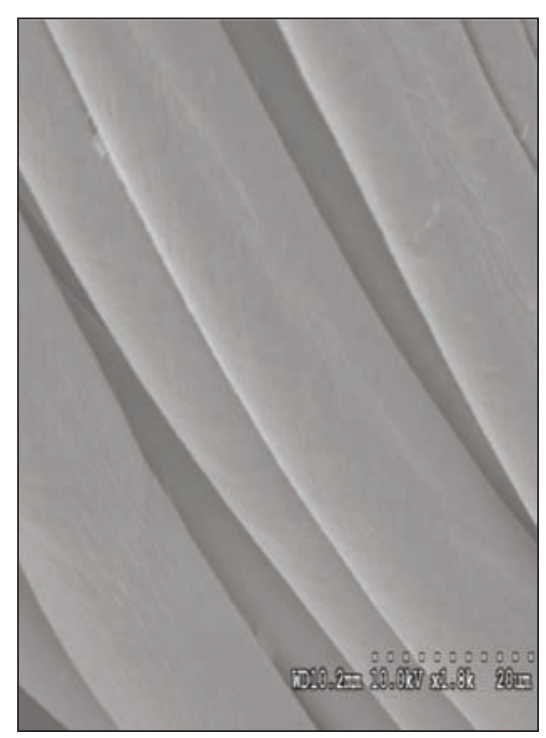

a

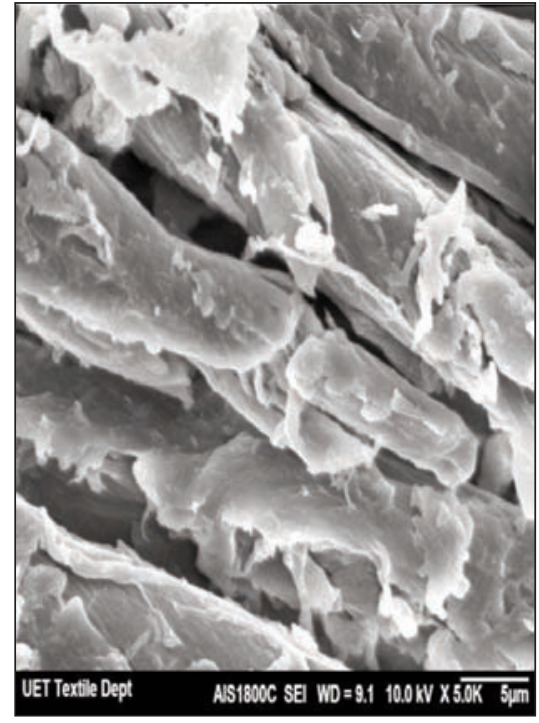

b

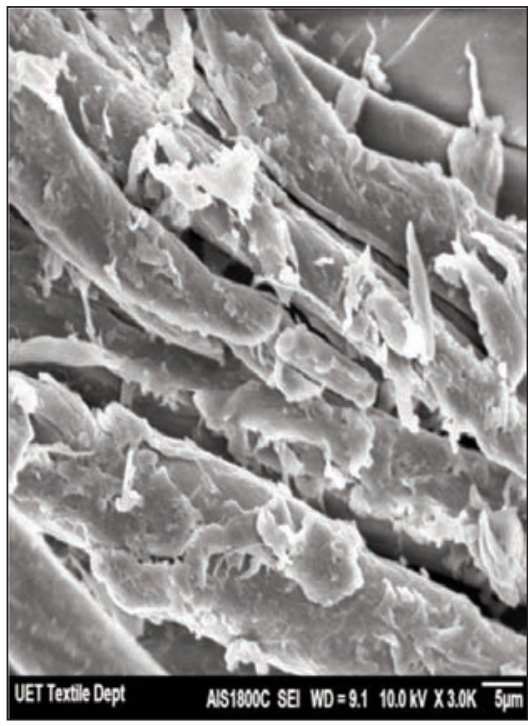

$c$

Fig. 3. SEM images of: $a$ - Untreated, $b$ - DAHP $10 \%+$ Maleic acid $10 \%+$ SHP $8 \%+\mathrm{K}_{2} \mathrm{~S}_{2} \mathrm{O}_{8} 0.2 \%$ at $120^{\circ} \mathrm{C}$ under nitrogen atmosphere, $c$ - DAHP $10 \%+$ Acrylic acid $10 \%+$ SHP $8 \%+\mathrm{K}_{2} \mathrm{~S}_{2} \mathrm{O}_{8} 0.2 \%$ at $90^{\circ} \mathrm{C}$ under nitrogen atmosphere

and initiator $0.2 \%$ (figure $3, b$ ). The figure 3,c exhibited the result when best recipe was applied on cotton fabric with respect to acrylic acid, DAHP, catalyst and initiator. Figures 3 , $b$ and $3, c$ confirmed the successful application of the both recipes onto the treated cotton fabric.

\section{Antimicrobial performance of finished cotton fabric}

It is quite well know that cotton

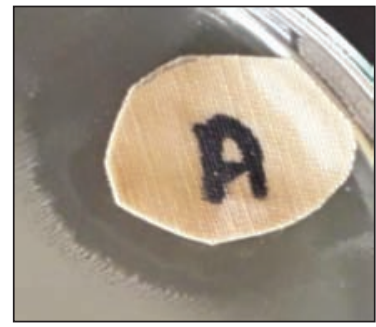

a

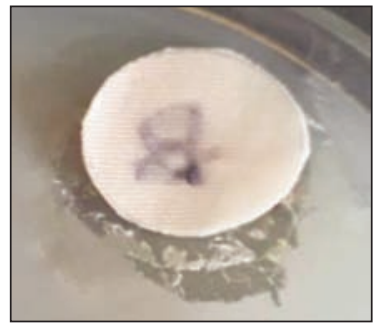

b

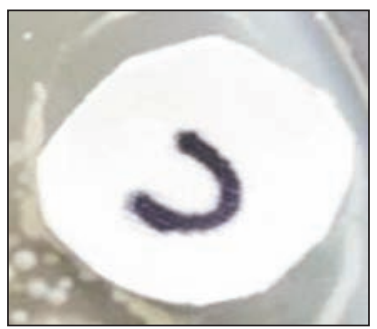

Fig. 4. a-DAHP 10\% + Acrylic acid 10\% + SHP $8 \%$ + Potassium per sufate $0.5 \%$ at $90^{\circ} \mathrm{C}$ under nitrogen atmosphere, $b-$ DAHP $10 \%+$ Maleic acid $10 \%+$ SHP $8 \%$ + Potassium per sulfate $0.2 \%$ at $120^{\circ} \mathrm{C}$ under nitrogen atmosphere, $c$ - untreated

is easily attacked by the microbes and same is demonstrated in our tests (figure 4,c). Both of the carboxylic acids; maleic acid and acrylic acid along with DAHP, catalyst and initiator treated fabric exhibited antimicrobial properties and clear zone of inhabitation of $0.20 \mathrm{~mm}$ and 0.82 $\mathrm{mm}$ respectively.

\section{CONCLUSION}

Halogen and formaldehyde free flame retardant have been synthesized by using the diammonium hydrogen phosphate and carboxylic acids like maleic acid and acrylic acid. The optimum results with respect to flame retardancy like limiting oxygen index and vertical burning were achieved when polymerization was carried out under nitrogen atmospherewith $\mathrm{K}_{2} \mathrm{~S}_{2} \mathrm{O}_{8}$ $0.2 \%$, sodium hypophosphite $8 \%$, diammonium hydrogen phosphate $10 \%$ along with maleic acid $10 \%$ and acrylic acid $10 \%$ at $120^{\circ} \mathrm{C}$ and $90^{\circ} \mathrm{C}$ respectively. There was also improvement in the burnt time of the smoldering cigarette test. 
Important additional properties of antimicrobial, crease recovery and better shrinkage control have been demonstrated by the optimum recipes. The successful synthesis and application of the newly recipes were confirmed by the FTIR analysis, phosphorous content and SEM analysis.

\section{ACKNOWLEDGEMENTS}

Authors are thankful to UET Lahore for funding this research project (No. ORIC-97/343).

\section{BIBLIOGRAPHY}

[1] Mohsin, M., Naveed, R., Qutab, H. G., Ahmad, S. W., Sarwar, N., Synthesis of halogen and formaldehyde free bio based fire retardant for cotton, In: Industria Textila, 2017, 68, 3, pp. 221-225

[2] Haynes, H. J. G., Fire loss in United States during 2015, In: National fire protection association, 2016

[3] Liu, Z., Xu, M., Wang, Q., Li, B., A novel durable flame retardant cotton fabric produced by surface chemical grafting of phosphorous - and - nitrogen containing compounds, In: Cellulose, 2017, 24, 9, pp. 4069-4081

[4] Gherasimescu, C., Butnaru, R., Leva, M., Mureşan, A., Manea, L. Z., Research regarding the optimization of flame retardant treatment for cellulose textile materials, In: Industria Textila, 2011, 62, 1, pp. 19-23

[5] Yasin, S., Behary, N., Giraud, S., Perwuelz, A., In situ degradation of organophosphorous flame retardant on cellulosic fabric using advanced oxidation process: A study on degradation and characterization, In: Polymer degradation and stability, 2016, 126, pp. 1-8.

[6] Salama, M., Bendak, A. Moller, M., Activating wool for flame-proof treatments with zirconium and titanium salts, In: Industria Textila, 2011, 62, 6, pp. 320-324.

[7] Mohsin, M., Ahmad, S. W., Khatri, A., Zahid, B., Performance enhancement of fire retardant finish with environment friendly bio cross-linker for cotton, In: Journal of cleaner production, 2013, 51, pp. 191-195

[8] Yang, C. Q., Wu, W., Xu, Y., The combination of a hydroxyl-functional organophosphorous oligomer and melamineformaldehyde as a retarding finishing system for cotton, In: Fire and materials, 2005, 29, pp. 109-120

[9] Wu, X., Yang, C. Q., Flame retardant Finishing of cotton fleece fabric, In: Journal of fire sciences, 2008, 26, pp. 351-368

[10] Samanta, A. K., Bagchi, A., Biswas, S. K., Fire retardant finishing of jute fabric and its thermal behavior using phosphorous and nitrogen based compound, In: Journal of Polymer Materials, 2011, 28, 149, pp. 149-169.

[11] Mohsin, M., Farooq, U., Ramzan, N., Rasheed, A., Ahmad, S., Ahsan, M., Softener impact on environment friendly low and zero formaldehyde cross-linker performance for cotton, In: Industria Textila, 2014, 65, pp. 134-139

[12] Mohsin, M., Ramzan, N., Ahmad, S. W., Afzal, A., Qutab, H. G., Development of environment friendly bio crosslinker finishing of silk fabric, In: Journal of natural fibers, 2015, 12, pp. 276-282

[13] Mohsin, M., Farooq, U., Raza, Z. A., Ahsan, M., Afzal, A., Nazir, A., Performance enhancement of wool fabric with environmentally friendly bio-cross-linker, In: Journal of cleaner production, 2014, 68, pp. 130-134

[14] Mohsin, M., Rasheed, A., Farooq, A., Ashraf, M., Shah, A., Environment friendly finishing of sulphur, vat, direct and reactive dyed cotton fabric, In: Journal of cleaner production, 2013, 53, pp. 341-347

[15] Mohsin, M., Sarwar, N., Ahmad, S., Rasheed, A., Ahmad, F., Afzal, A., Zafar, S., Maleic acid cross linking of C-6 fluorocarbon as oil and water repellent finish on cellulosic fabrics, In: Journal of cleaner production, 2016, 112, pp. $3525-3530$

[16] Salaun, F., Vroman, I., Influence of core materials on thermal properties of melamine - formaldehyde microcapsules, In: European polymer journal, 2008, 44, pp. 849-860

[17] Olsen, S. R., Cole, C. V., Watanabe, F. S., Dean, L., A., Estimation of available phosphorous in soils by extraction with sodium bicarbonate, 1954, U.S. Dep. Agric. Circ. 939, USA

\section{Authors:}

\section{HAJI GHULAM QUTAB ${ }^{1}$, MUHAMMAD MOHSIN², NAVEED RAMZAN ${ }^{3}$,} SYED WAQAS AHMAD ${ }^{1}$, ELENA CORNELIA MITRAN ${ }^{4}$

${ }^{1}$ Department of Chemical Engineering, UET Lahore, Faisalabad Campus, Pakistan

${ }^{2}$ Department of Textile Engineering, UET Lahore, Faisalabad Campus, Pakistan e-mail: mohsinmalikntu@yahoo.com

${ }^{3}$ Department of Chemical Engineering, UET Lahore, Main Campus, Pakistan

${ }^{4}$ The National Research and Development Institute for Textiles sand Leather, Bucharest, Romania e-mail: office@incdtp.ro

Corresponding author:

Dr. MUHAMMAD MOHSIN

e-mail: mohsinmalikntu@yahoo.com 